\title{
IMPLEMENTASI MANAJEMEN STRATEGIK SYARIAH DI BMT AMANAH UMMAH')
}

\author{
Muhammad Niltal Muna \\ Mahasiswa Program Studi S1 Ekonomi Islam-Fakultas Ekonomi dan Bisnis -Universitas Airlangga
} Email : niltalmuna@gmail.com

Meri Indri Hapsari

Departemen Ekonomi Syariah-Fakultas Ekonomi dan Bisnis-Universitas Airlangga Email : meri.indri@gmail.com

\begin{abstract}
:
The aim of this research is to know implementation of Sharia Strategic Manajemen in BMT. The research object is BMT Amanah Ummah Surabaya. The research method used in this research are qualitative research, case study, and domain analysis, taksonomy analysis and componensial analysis. By using data collection technique such as interviewing and observing primary informant (BMT Amanah Ummah Management) and secondary informant (Sharia Supervisory Council) for data validity.

The result of this research is the BMT Amanah Ummah has applied steps of sharia strategic management very well. Those adjustments can be seen from the steps of sharia strategic management start from strategy formulating, strategy implementing, and strategy evaluating. The indicators of this research are the process of strategic management done by BMT Amanah Ummah adjusted to Fred R. David concept, and the sharia principals used for process of sharia strategic management adjusted to maqashid sharia.
\end{abstract}

Keywords : Sharia Strategic Management, BMT Amanah Ummah, maqashid sharia

\section{PENDAHULUAN}

\section{Latar Belakang}

Dewasa ini lembaga keuangan syariah di Indonesia semakin berkembang, baik bank ataupun lembaga keuangan non bank. Perkembangan dan dinamika lembaga keuangan di Indonesia mencatat peningkatan kuantitas yang cukup signifikan. Kondisi tersebut mendorong peningkatan kualitas dari lembaga keuangan tersebut untuk dapat memenuhi kebutuhan bisnis dan keuangan masa kini namun tetap dalam prinsip-prinsip Islam.

Pada penelitian ini penulis membatasi objek penelitian yaitu hanya BMT saja. BMT adalah kependekan dari kata Balai Usaha Mandiri Terpadu atau Baitul Maal wat Tamwil, yaitu suatu
Lembaga Keuangan Mikro (LKM) yang beroperasi berdasarkan prinsip-prinsip syariah (Soemitra, 2009).

Akan tetapi beberapa dari BMT gagal bertahan dan bankrut akibat kurangnya dukungan dan pengawasan yang tepat (Seibel, 2008). Warjiyo (2004:63) mengatakan bahwa untuk menghindari hal tersebut, sebelum melakukan pembiayaan lembaga keuangan harus lebih dahulu mencari informasi untuk menilai kelayakan calon debitur yang mengajukan permohonan untuk memperoleh pembiayaan. Salah satu sumber informasi dalam pemberian pembiayaan adalah informasi akuntansi yang meliputi neraca, laporan laba rugi, laporan arus kas, dan rasio-rasio keuangan.

1) Jurnal ini merupakan bagian skripsi dari Muhammad Niltal Muna, NIM : 041114081 , yang diuji pada tanggal 09 Agustus 2015 
Arifin (2005:85) menjelaskan bahwa menjaga likuiditas dinilai penting sebab pada dasarnya kegiatan intermediasi merupakan bisnis kepercayaan dimana dana dari pada pihak yang menyimpan dananya pada lembaga keuangan, lalu pihak lembaga keuangan meyalurkan dalam bentuk pembiayaan kepada pihak yang membutuhkan.

Berkaitan dengan sistem monitoring pembiayaan dilakukan oleh BMT, Muhammad (2004) berpendapat bahwa BMT harus menerapkan konsep kehati-hatian (prudential concept) dalam memberikan pembiayaan. Tentunya terdapat banyak faktor yang mempengaruhi, salah satunya pada kualitas Sumber Daya Manusia (SDM) pada organisasi tersebut. Oleh karena itu,dibutuhkan peran manajemen strategikuntuk membantu lembaga keuangan merumuskan strategi-strategi yang lebih baik melalui penggunaan strategi yang lebih sistematis, logis dan rasional (David, 2011:23). Penerapan manajemen strategik yang optimal tentu akan menciptakan suatu rencana kerja yang jelas terkait bagaimana pembiayaan tersebut disalurkan, bagaimana meningkatkan kinerja dan mengembangkan organisasi menjadi lebih besar dan dapat bersaing dengan organisasi yang lain serta bagaiamana organisasi dapat terus tumbuh dan melakukan kegiatan usaha dengan berkesinambungan (sustainable).

\section{Rumusan Masalah}

Berdasarkan uraian latar belakang diatas, maka penulis ingin mengajukan rumusan masalah dalam penelitian ini adalah

"Bagaimana implementasi manajemen strategik syariah di BMT Amanah Ummah?"

\section{Tujuan Penelitian}

"Untuk mengetahui implementasi manajemen strategik syariah di BMT Amanah Ummah"

\section{TINJAUAN PUSTAKA}

Manajemen Strategik Dalam Perspektif Islam

Pada dasarnya Islam telah mengajarkan bahwa hakikat amal perbuatan haruslah berorientasi bagi pencapaian ridha Allah SWT. Oleh karena itu sebaiknya dalam melakukan kegiatan usaha, maka suatu organisasi tidak hanya fokus mencari profit yang berupa materi, akan tetapi juga mencari keridhaan Allah.

\section{Proses Manajemen Strategik Syariah}

Pada dasarnya proses manajemen strategik mempunyai tiga pertanyaan dasar, yaitu mau dibawa kemanakah suatu organisasi, mau kemana organisasi tersebut, bagaimana organisasi tersebut mencapainya. Beekun (2011:5) mengatakan bahwa manajemen strategik syariah pada dasarnya berhubungan dengan perilaku organisasi dalam internal organisasi dan eksternal organisasi, proses, struktur organisasi, dan keputusan yang diambil dalam rangka mencapai tujuan. Manajemen strategik syariah melibatkan dua tahapan yang penting yaitu 
perumusan strategi dan implementasi strategi. Menurut Beekun (2011:5) menyatakan bahwa perumusan strategi relatif lebih mudah daripada implementasi strategi yang dipandang lebih menantang, dan pada tahapan implementasi strategi semua anggota organisasi ikut terlibat.

Organisasi Islam dipandang jarang melibatkan implementasi, organisasi Islam sering melupakan bahwa pemikiran yang strategis butuh untuk membangun keseluruhan organisasi. Dalam manajemen strategik syariah tidak hanya sekedar mengintegrasikan model manajemen yang telah ada akan tetapi juga terdapat nilai-nilai Islam dan benefit sebagai intinya. Beekun(2011:9) menjelaskan bahwa seharusnya proses manajemen strategi harus menyeluruh mencakup perumusan strategi dan implementasi strategi seperti penilaian kinerja dan menekankan pengawasan etika dan peraturan.

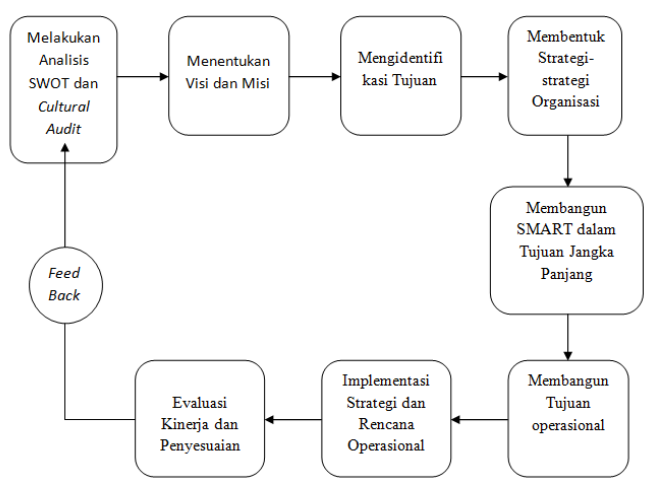

a. Melakukan Analisis SWOT dan Cultural

\section{Audit}

Di dalam Islam, setiap manusia pasti diberikan kekuatan dan kelemahan di dalam dirinya, oleh karena itu setiap manusia harus mampu memanfaatkan potensi diri dan menyadari kelemahan dan kekuatan sehingga mampu menjadi khilafah. Menurut Karebet (2003:47) penilaian internal dan eksternal dapat dilakukan mengacu pada Al-Qur'an sebagai pedoman untuk manusia, termasuk dalam melakukan analisa internal dan eksternal. Seperti dijelaskan pada surat Al-Baqarah berikut ini:

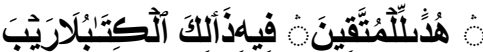

Dzaalika alkitaabu laa rayba fiihi hudan lilmuttaquina

Artinya: Kitab (Al Quran) ini tidak ada keraguan padanya; petunjuk bagi mereka yang bertakwa

$$
\text { Cultural Audit merupakan }
$$
penilaian terhadap budaya yang sedang berlaku dalam suatu organisasi. Tujuan dasar dari cultural audit ini adalah untuk memastikan budaya organisasi sesuai dan memiliki efek positif pada organisasi dan misi organisasi. Cultural Audit mengukur budaya organisasi yang dilakukan dengan cara mengukur persepsi individual terhadap setiap dimensi budaya yang berlaku saat ini serta persepsi idealnya. Tujuan dari cultural audit adalah nilai yang terkandung dalam pemikiran organisasi baik dari pemikiran individu atau pemikiran kelompok.

\section{b. Menentukan Visi dan Misi}

$$
\text { Menurut Beekun }
$$

perumusan strategi dapat diartikan sebagai proses yang membimbing anggota organisasi terkait cara pandang yang diharapkan kedepannya, dan 
mengembangkan prosedur-prosedur dan operasional yang diperlukan sebagai bentuk ibadah kepada Allah, yang merupakan salah satu tujuan utama manajemen strategik syariah. Dalam hadist Muslim nomor 4810 :

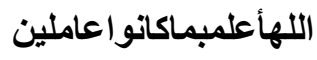

Allahu'alambimaakaanuv 'amaliyn

Artinya: Allah lebih mengetahui apa yang mereka kerjakan.

Visi menurut Beekun (2011:42) adalah cara pandang yang menyeluruh dan futuristik terhadap keberadaan organisasi. Pernyataan visi menjawab pertanyaan, akan menjadi sosok organisasi yang seperti apa pada masa yang akan datang.

Pengembangan visi berdasarkan manajemen strategik syariah menurut Beekun (2011) adalah organisasi yang harus membuat perumusan dan kerangka dasar yang dilandasi dengan kemauan untuk mencari keuntungan dan keberkahan, dimana sebelum membuat visi, sebaiknya berdoa dan bertawakal pada Allah

Visi dan misi yang sesuai syariah berlandaskan iman kepada Allah dan Rasul-Nya atau menjalankan segala perintah dan menjauhi larangan Allah dan Rasul-Nya. Dengan demikian perilaku dalam bisnis hendaknya sesuai dengan yang dianjurkan oleh Allah, mengindari yang dilarang Allah serta menjauhi produk yang dilarang oleh Allah dan Rasul-Nya. Strategi bisnis yang sesuai syariah adalah berupaya dengan sungguh-sungguh di jalan Allah dengan mengelola sumberdaya secara optimal untuk mencapai tujuan yang terbaik di sisi Allah, baik di dunia maupun di akhirat. Sedangkan tujuan bisnis yang sesuai syariah adalah mendapat keuntungan yang besar baik di dunia maupun di akhirat.

\section{c. Mengidentifikasi Tujuan}

Menurut Beekun (2011:55) tujuan (goals) merupakan akhir dari proses organisasi yang telah dicapai melalui eksistensi dan operasinya serta merupakan sasaran yang lebih nyata dari pernyataan misi. Karebet menjelasksan bahwa tujuan dalam perspektif Islam tidak semata-mata hanya berorientasi kepada hal materi tetapi juga sebagai bentuk ibadah kepada Allah SWT

\section{d. Membentuk Strategi Organisasi}

$$
\text { Beekun (2011:66) Proses }
$$

membentuk strategi organisasi yang harus diperhatikan adalah sebagai berikut:

1) Forward Looking: berlandaskan situasi organisasi dan pencapaian organisasi

2) Proactive: Strategi yang ditentukan haruslah proaktif terhadap semua yang dilakukan baik dari kompetitor ataupun dari faktor eksternal lingkungan.

3) Dynamic: Para pimpinan organisasi hendaknya harus siap dalam menghadapi dinamika usaha yang terus berubah-ubah.

4) Memberikan Value: pada proses manajemen strategik syariah tidak hanya sekedar memberikan manfaat kepada para stakeholders saja. 


\section{e. Membentuk SMART Dalam Tujuan Jangka Panjang}

Kriteria SMART adalah Specific, Measurable, Acceptable, Realistic, Time Bound. Dalam menentukan tujuan jangka panjang kelima aspek tersebut harus ada. Berikut penjelasan kelima aspek tersebut:

1) Spesific: Apa yang menjadi fokus organisasi haruslah jelas.

2) Measurable: Dalam menentukan tujuan organisasi haruslah terukur dan dapat dihitung jumlahnya yang ingin dicapai.

3) Acceptable: Suatu tujuan harus dapat diterima oleh semua anggota organisasi.

4) Realistic: Tujuan yang baik adalah yang realistik, tidak mengandai-andai, karena hal tersebut hanya akan membuang waktu dan merusak internal organisasi.

5) Time Bound: Batas waktu tujuan tersebut dapat direalisasikan, batas waktu ini merupakan hal yang penting agar tujuan yang telah ditentukan dapat segera diraih. Selain itu juga motivasi oleh seluruh anggora organisasi dalam mencapai tujuan tersebut.

\section{f. Implementasi Manajemen Strategik}

\section{Syariah}

Implementasi strategi merupakan tahapan setelah perumusan strategi, implementasi pada manajemen strategi konvensional menerapkan konsep dari Michael R. Porter dengan strategi generiknya yang meliputi: kepemimpinan biaya menyeluruh, diferensiasi, dan fokus, sedangkan implementasi menurut prinsip Islam dalam strategi berwujud pada difungsikannya Islam sebagai kaidah berpikir dan juga kaidah amal dalam seluruh kegiatan usaha organisasi. Nilainilai Islam inilah sesungguhnya merupakan nilai utama aktivitas organisasi. Dari paparan tersebut dapat katakan bahwa segala seutau harus direncanakan dan terorganisir dengan baik.

Aktivitas perusahaan apapun bentuknya, pada hakikatnya adalah aktivitas individu dalam memenuhi kebutuhan hidupnya yang sesuai dengan tuntutan syari'ah. Sesuai dengan yang dijelaskan oleh AlQur'an:

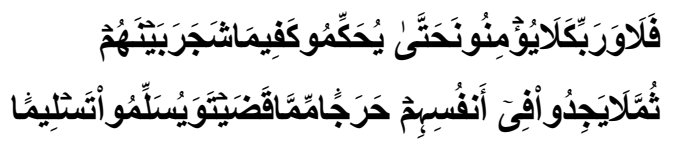

Falaa warabbika laa yu'minuuna hattaa yuhakkimuuka fiimaa syajara baynahum tsumma laa yajiduu fii anfusihim harajan mimmaaqadhayta wayusallimuu tasliimaan

Artinya: "Maka demi Rabbmu, mereka pada hakekatnya tidak beriman, hingga mereka menjadikan kamu sebagai hakim dalam perkara yang mereka perselisihkan kemudian mereka tidak merasa keberatan terhadap keputusan yang kamu berikan dan mereka menerima dengan sepenuhnya" (QS An-Nisaa, 4:65)

\section{g. Evaluasi Manajemen Strategik Syariah}

Evaluasi strategi dalam manajemen strategik syariah mempunyai fungsi yaitu untuk meluruskan suatu hal yang tidak lurus, mengoreksi sesuatu yang salah dan membenarkan yang sesuai dengan syariat. Tahapan akhir dari proses manajemen strategik adalah evaluasi, yaitu penilaian kinerja dan pengawasan 
yang berlanjut dengan berjalannya proses umpan balik. Penilaian kinerja dilakukan sesuai dengan prosedur organisasi yang dikembangkan, yakni dengan mengacu pada tolak ukur dan operasional. Hal ini guna mendapatkan kepastian akan ketepatan pencapaian strategi induk organisasi. Apapun hasilnya, akan menjadi rekomendasi masukan bagi perbaikan dan penyempurnaan stratregi dan implementasi berikutnya.

\section{Baitul Maal Wat Tamwil (BMT)}

BMT atau yang lebih dikenal sebagai Baitul Maal Wat Tamwil atau Balai Usaha Mandiri Terpadu merupakan suatu lembaga keuangan mikro (LKM) yang beroperasi berdasarkan prinsip-prinsip syariah. Menurut Soemitra (2009:451) BMT mempunyai dua fungsi utama yaitu :

a. Baitul tamwil (rumah pengembangan harta), yaitu melakukan kegiatan pengembangan usaha-usaha produktif dan investasi dalam meningkatkan kualitas ekonomi pengusaha mikro dan kecil dengan cara mendorong kegiatan menabung dan menunjang pembiayaan kegiatan ekonomi.

b. Baitul maal (rumah harta), merupakan titipan dana zakat, infak, dan sedekah serta mengoptimalkan distribusinya sesuai dengan peraturan dan amanahnya.

Dilihat dari konteks masa sekarang Baitul Maal dimasa itu menjalankan fungsi sebagai Departemen Keuangan, Departemen Sosial dll. Namun pengertian "Baitul Maal" dalam konteks istilah BMT kini lebih menyempit maknanya. Baitul Maal dalam konteks BMT hanya menjalankan fungsi social yang lepas dari kaitan politik Negara. Baitul Maal dalam kaitan BMT mempunyai kegiatan yang menyempit yaitu hanya menerima dan menyalurkan zakat, infak, shodaqoh (ZIS) yang tidak bersifat komersial.

\section{Tujuan BMT}

Menurut Soemitra (2009:452) tujuan BMT yaitu meningkatkan kualitas usaha ekonomi untuk kesejahteraan anggota pada khususnya dan masyarakat pada umumnya. Pengertian tersebut dapat dipahami mengingat BMT berorientasi pada usaha peningkatan kesejahteraan anggota dan masyarakat. Anggota harus diberdayakan (empowering) supaya dapat mandiri.

\section{Fungsi BMT}

Soemitra (2009:453) berpendapat bahwa fungsi BMT meliputi lima aspek, yaitu :

a. Mengidentifikasi, memobilisasi, mengorganisasi, mendorong dan mengembangkan potensi serta kemampuan potensi ekonomi anggota, kelompok anggota muamalat (pokusma) dan daerah kerjanya.

b. Meningkatkan kualitas SDM anggota dan pokusma menjadi lebih profesional dan Islami sehingga semakin utuh dan tangguh dalam mengahadapi persaingan global.

C. Menggalang dan memobilisasi potensi masyarakat dalam rangka meningkatkan kesejahteraan anggota.

d. Menjadi perantara keuangan (financial 
intermediary) antara orang kaya sebagai shohibul maal dengan dhu'afa sebagai mudharib, terutama untuk dana-dana sosial seperti zakat, infak, shadaqoh, wakaf, hibah dll.

e. Menjadi perantara keuangan antara pemilik dana baik sebagai pemodal maupun penyimpan dengan pengguna dana (mudarib) untuk mengembangkan usaha produktif.

\section{METODE PENELITIAN}

\section{Prosedur Pengumpulan Data}

Sugiyono (2005:68) mengatakan bahwa terdapat tiga tahapan prosedur penelitian pada umumnya, yaitu:

a. Survey Pendahuluan

Dilaksanakan dengan tujuan untuk mendapatkan gambaran umum mengenai company profile BMT Amanah Ummah.yang berkaitan dengan masalah yang akan diteliti.

b. Studi Kepustakaan

Prosedur ini dilaksanakan dengan tujuan untuk memperoleh landasan teori dan implementasinya melalui literatur, laporan, makalah, jurnal, dan artikel yang berkaitan dengan permasalahan yang ada serta berguna bagi penyusunan skripsi. Studi kepustakaan difokuskan pada literatur mengenai manajemen strategik, manajemen strategik syariah dan BMT

c. Penelitian Lapangan

Langkah ini bertujuan untuk melihat secara lebih jelas serta memperoleh data yang akurat sebagai masukan dalam proses analisis selanjutnya.

\subsection{Unit Analisis}

Menurut Moleong (2006: 130) unit analisis adalah suatu hal yang berkaitan langsung dalam proses penelitian dapat berupa benda, individu, kelompok ataupun organisasi. Dalam hal ini yang menjadi unit analisisnya adalah proses implementasi manajemen strategik syariah di BMT Amanah Ummah.

\subsection{Teknik Analisis}

Setelah melakukan pengumpulan data, maka tahap berikutnya adalah melakukan analisa data. Menurut Spradley dalam Sugiyono (2005:255) menjelaskan bahwa terdapat tiga teknik analisa data, yaitu :

a. Analisis Domain, yaitu suatu analisa yang dilakukan untuk memperoleh gambaran umum dan menyeluruh dari suatu obyek penelitian, sehingga ditemukan berbagai domain atau kateori yang didapat dari pertanyaan grand dan minitour. Peneliti menetapkan domain tertentu sebagai pijakan untuk penelitian selanjutnya. Terdapat empat domain yang dilakukan oleh peneliti, yaitu perumusan strategi, implementasi strategi, evaluasi strategi dan prinsip syariah yang digunakan dalam proses manajemen strategik syariah.

b. Analisis Taksonomi, setelah domain ditentukan, maka tahap selanjutnya adalah menjabarkan menjadi rincian domain. Rincian domain yang ditentukan adalah sebagai berikut: 


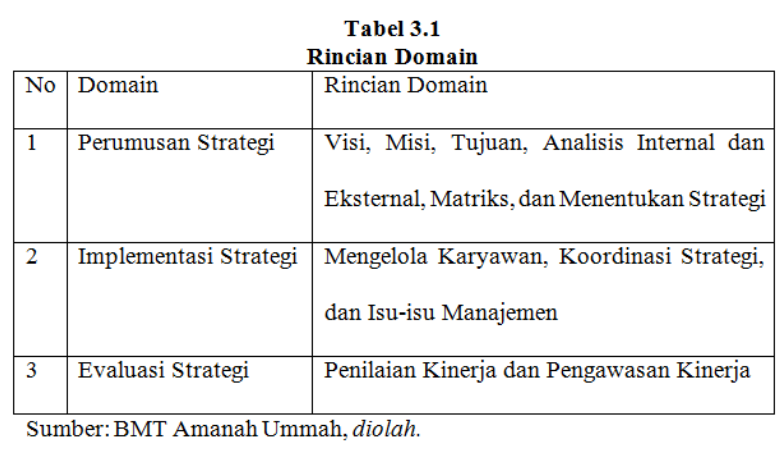

\subsection{Teknik Validasi}

Data yang diperoleh dari observasi dan wawancara selanjutnya diuji kredibilitasnya dengan cara triangulasi. Tujuan dari triangulasi bukan untuk mencari kebenaran tentang beberapa fenomena, melainkan dengan tujuan untuk meningkatkan pemahaman peneliti terhadap apa yang telah ditemukan. Teknik triangulasi yang digunakan adalah sebagai berikut

Untuk menguji kebenaran data dilakukan dengan cara mengecek data yang telah diperoleh melalui beberapa sumber. Misalnya, selain melalui wawancara dan observasi, peneliti bisa menggunakan observasi terlibat (participant observation), dokumen tertulis, arsip, dokumen sejarah, catatan resmi, catatan atau tulisan pribadi dan gambar atau foto. Dari metode ini, penulis akan membandingkan keselarasan antara wawancara dengan pihak terkait, observasi, dan dibuktikan dengan arsip dokumen yang ada, sehingga data yang didapatkan akurat dan dapat dipertanggungjawabkan.

\section{HASIL DAN PEMBAHASAN}

\section{Perumusan Strategi}

\section{a. Visi, Misi, dan Tujuan}

Pada dasarnya proses perumusan visi, misi dan tujuan yang dilakukan BMT Amanah Ummah sudah sesuai dengan prosedur dalam proses perumusan strategi yang sesuai dengan teori Fred R. David, hal tersebut dapat dilihat dari proses perumusan strategi di BMT Amanah Ummah dilakukan dengan cara rapat dan musyawarah yang dilakukan oleh para pengurus dengan seluruh para staff. Visi, misi dan tujuan yang dirumuskan tersebut digunakan sebagai pedoman dalam melaksanakan kegiatan organisasi. Hal tersebut dapat dilihat dari visi, misi, dan tujuan BMT Amanah Ummah yang berorientasi tidak hanya sekedar pada profit dan kemajuan anggotanya, tetapi juga terdapat nilai maqashid syariah dan kemaslahatan dalam menentukan visi, misi, dan tujuan tersebut.Dalam hal ini maqashid syariah yang dimaksud adalah untuk kebutuhan masyarakat secara umum. Sedangkan cara untuk tercapai kemaslahatan tersebut manusia harus memenuhi kebutuhan dharuriat (Primer), dan menyempurnakan kebutuhan hajiyat (sekunder), dan Tahsiniat (tersier). Seperti yang disampaikan Allah dalam Al-Qur'an surat Al-Anbiya ayat 107:

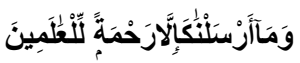

wamaa arsalnaaka illaa rahmatan lil'aalamiina

Artinya: Dan tiadalah Kami mengutus kamu, melainkan untuk (menjadi) rahmat bagi semesta alam. (Q.S Al-Anbiyaa', 
21:107)

Selain itu dalam surat Al-Baqarah ayat 201:

ومنهمنيقولربنآتنافيالدنياحسنةوفيالآخرةّسنةوقناعذابالنار waminhum man yaquulu rabbanaa aatinaa fii alddunyaa hasanatan wafii alaakhirati hasanatan waqinaa 'adzaaba alnnaari

Artinya: Dan di antara mereka ada orang yang bendo'a: "Ya Tuhan kami, berilah kami kebaikan di dunia dan kebaikan di akhirat dan peliharalah kami dari siksa neraka. (Q.S Al-Baqarah, 2:201)

BMT Amanah Ummah menentukan ketiga hal tersebut pada dasarnya dilandasi dengan niat berdakwah untuk menyampaikan sekaligus mengenalkan ekonomi syariah kepada masyarakat. Hal tersebut didasari atas kurangnya pengetahuan masyarakat terhadap lembaga keuangan syariah khususnya BMT.

Pada dasarnya visi merupakan salah satu hal yang penting dalam setiap organisasi, visi merupakan jati diri suatu organisasi, akan dibawa kemanakah suatu organisasi dapat dilihat dari visi organisasi tersebut. Begitu pula dengan BMT Amanah Ummah yang mempunyai visi "Dengan Ridlo Allah menjadi Koperasi Syariah Terdepan dan Tedekat di Hati Masyarakat Ekonomi Mikro, Kecil dan Menengah". Visi tersebut menjelaskan bahwa BMT Amanah Ummah mempunyai cita-cita menjadi Koperasi Syariah yang tidak hanya dikenal di masyarakat tetapi menjadi top of mind di masyarakat.
Misi menurut BMT Amanah Ummah merupakan hal yang terpenting dalam kegiatan operasional organisasi. Pada dasarnya BMT Amanah Ummah berbeda dengan organisasi lain yang mayoritas menentukan visi terlebih dahulu kemudian menentukan misi untuk mencapai visi organisasi tersebut. Berbeda dengan BMT Amanah Ummah yang menentukan misi terlebih dahulu kemudian menentukan visi. BMT Amanah Ummah memiliki pandangan tersendiri bahwa pada dasarnya yang dapat berubah adalah visinya bukanlah misinya. Misi haruslah menjadi dasar dalam kegiatan operasional organisasi, sedangkan visi dapat berubah sesuai dinamika kegiatan usaha. BMT Amanah Ummah memiliki misi sebagai berikut :

1) Memberikan Pelayanan dan Pendampingan Masyarakat Usaha Mikro Kecil Menengah untuk meningkatkan kualitas hidup.

2) Membudayakan dan Mendekatkan Masyarakat pada Lembaga Kevangan Syariah dan Bermuamalah secara Syariah.

BMT Amanah Ummah melakukan proses kegiatan berlandaskan dakwah dan juga bisnis. Menurut BMT Amanah Ummah misi merupakan dasar kegiatan usaha usaha tersebut didirikan dari apa, untuk apa dan kenapa didirikan.BMT Amanah Ummah ingin melakukan hal yang sama seperti cara Rasulullah Muhammad SAW dalam menyebarkan agama Islam. Karena yang diutamakan Rasulullah adalah misinya terlebih dahulu 
yaitu cara menyampaikan ajaran agama yang lebih penting, maka dalam hal ini BMT Amanah menjadikan misi sebagai jati diri organisasi.

Adapun tujuan jangka panjang untuk masyarakat adalah mendekatkan masyarakat pada lembaga keuangan syariah dan bermuamalah secara syariah. Hal tersebut sejalan dengan misi yang ditentukan oleh BMT Amanah Ummah dengan tujuan menyampaikan sekaligus mengenalkan masyarakat kepada lembaga keuangan syariah khususnya BMT.

Sedangkan tujuan jangka panjang yang kedua yaitu pengembangan organisasi sangat diperlukan karena selain untuk menambah asset organisasi, pengembangan organisasi juga dapat menyerap tenaga kerja.

\section{b. Analisis Internal dan Eksternal}

Tahapan proses perumusan strategi yang selanjutnya adalah analisis internal organisasi dan analisis lingkungan eksternal organisasi. Dalam proses analisis internal organisasi tersebut digunakan untuk mengetahui kelebihan dan kekurangan dari BMT Amanah Ummah. Dalam hal ini BMT Amanah Ummah melakukan analisis internal seperti teori Fred R.David yaitu menggunakan pendekatan sumber daya yang dimiliki (Resources Based View). BMT Amanah Ummah berupaya agar sumber daya yang dimiliki tersebut dapat digunakan secara optimal, baik itu dari SDM, aset, dan kapabilitas Pada hal ini BMT Amanah Ummah mempunyai cara dalam menganalisa lingkungan internal yaitu dengan melakukan pendekatan fungsional yaitu dengan cara menganalisa kinerja Sumber Daya Manusia (SDM), kinerja keuangan, dan kinerja pemasaran. Untuk mengetahui kinerja tersebut maka BMT Amanah Ummah melakukan rapat dan musyawarah setiap bulan guna mengetahui apa saja kelebihan atau capaian kinerja yang telah diraih dan kekurangan atau kendala dalam melakukan kegiatan operasionalnya.

Sedangkan analisa lingkungan eksternal BMT Amanah Ummah dilakukan dengan cara membagi dua jenis analisa lingkungan eksternal, yang pertama yaitu lingkungan jauh yaitu dengan menganalisa faktor-faktor seperti faktor ekonomi, faktor politik, dan faktor sosial. Kemudian yang kedua yaitu lingkungan industri yaitu dengan menganalisa lingkup industri lembaga keuangan syariah.

\section{c. Matriks dan Menentukan Strategi}

Setelah melakukan analisis internal orgnanisasi dan eksternal organisasi, maka tahapan selanjutnya dalam proses perumusan strategi yaitu menentukan matriks kemudian menentukan strategi. Dalam menentukan matriks perlu adanya hasil dari analisis internal organisasi dan analisis ekternal organisasi, dalam hal ini BMT Amanah Ummah menggunakan matriks Strength Weakness Opportunity 
and Threat (SWOT). Matriks SWOT dirasa cocok untuk menentukan strategi kedepannya, metode SWOT menekankan pada kondisi internal BMT Amanah Ummah. Dari hal itu BMT Amanah Ummah dapat melihat kekuatan ataupun kelemahan yang ada di internal organisasi. Matriks SWOT juga digunakan BMT Amanah dalam menyusun anggarananggaran kegiatan dan biaya, dan menentukan strategi kedepannya.

\section{Implementasi Strategi}

Setelah proses perumusan strategi yang selanjutnya adalah proses implementasi strategi, dalam implementasi strategi terdapat bagaimana cara mengelola karyawan dan mengkoordinasikan strategi yang telah ditentukan kepada seluruh karyawan. Dalam hal mengelola karyawan BMT Amanah Ummah mengelolanya agar sebaik mungkin agar karyawan loyal dan senantiasa dapat dibina agar kegiatan usaha dapat berlangsung dengan baik. BMT Amanah Ummah memberikan upah yang sesuai dengan jabatan dan kinerja setiap karyawan, selain itu juga terdapat tunjangan, asuransi, vang transport dan vang makan.

BMT Amanah Ummah ingin memberikan timbal balik yang baik dengan seluruh karyawan. Selain itu BMT Amanah Ummah memberikan motivasi dan coaching agar para pegawai selalu senantiasa termotivasi dan mendapatkan ilmu yang bermanfaat. Layaknya perbankan syariah pada umumnya BMT Amanah Ummah ingin benar-benar mengoptimalkan sumber daya yang ada khususnya di bidang SDM. BMT Amanah Ummah juga rutin mengadakan gathering dan outbound layaknya perbankan pada umumnya.

Selain itu BMT Amanah Ummah juga menganut sistem reward and punsihment, promosi jenjang karir dan insentif diberikan kepada para karyawan yang mempunyai kinerja yang bagus dan dapat memenuhi target yang telah ditetapkan, sedangkan bagi karyawan yang tidak dapat memenuhi target dan terlebih lagi merugikan secara material maka akan mendapatkan punishment yang berupa rotasi jabatan, penurunan jabatan hingga PHK. Oleh karena itu BMT Amanah Ummah ingin mempunyai SDM yang berkualitas tidak hanya ilmunya tetapi juga akhlak dan kinerjanya.Seperti dalam Al-Qur'an surat At-Taubah ayat 119:

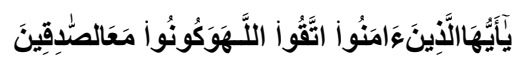
yaa ayyuhaa alladziina aamanuv ittaque allaaha wakuunuu ma'a alshshaadiqiina Artinya: Hai orang-orang yang beriman bertakwalah kepada Allah, dan hendaklah kamu bersama orang-orang yang benar. (Q.S At-Taubah, 9:119)

\section{Evaluasi Strategi}

Pada proses yang terakhir yaitu evaluasi strategi merupakan tahap akhir dalam proses manajemen strategik 
syariah sekaligus menjadi tahapan yang paling penting karena evaluasi strategi menentukan apakah visi, misi, tujuan, dan strategi yang telah dirumuskan dan diterapkan dapat diteruskan atau harus diganti. Dalam proses evaluasi strategi, BMT Amanah Ummah melakukannya dengan cara rapat aggota tahunan dan musyawarah. Rapat dan musyawarah tersebut atas hasil laporan keuangan dan laporan kinerja karyawan. Rapat dan musyawarah dilakukan untuk menentukan jumlah anggaran, menentukan strategi apabila ada perubahan, dan merumuskan visi apabila ada perubahan. Al-Qur'an menjelaskan dalam Surat AliImran ayat 159 tentang pentingnya musyawarah:

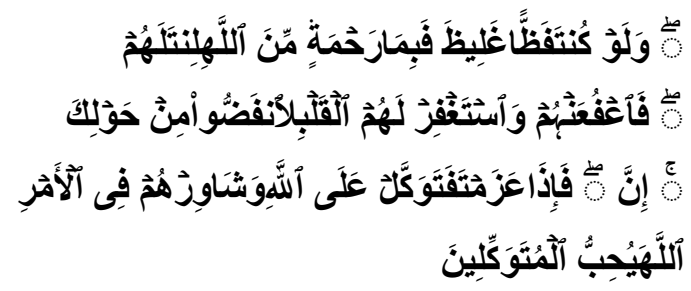

fabimaa rahmatin mina allaahi linta lahum walaw kunta fazhzhan ghaliizha alqalbi lainfadhdhuu min hawlika fau'fu 'anhum waistaghfir lahum wasyaawirhum fii al-amri fa-idzaa 'azamta fatawakkal 'alaa allaahi inna allaaha yuhibbu almutawakkiliina

Artinya: Maka disebabkan rahmat dari Allah-lah kamu berlaku lemah lembut terhadap mereka. Sekiranya kamu bersikap keras lagi berhati kasar, tentulah mereka menjauhkan diri dari sekelilingmu. Karena itu maafkanlah mereka, mohonkanlah ampun bagi mereka, dan bermusyawaratlah dengan mereka dalam urusan itu. Kemudian apabila kamu telah

$\begin{array}{llr}\text { membulatkan } & \text { tekad, } & \text { maka } \\ \text { bertawakkallah } & \text { kepada } & \text { Allah. } \\ \text { Sesungguhnya Allah menyukai orang- } & \text { orang yang bertawakkal kepada-Nya. } \\ \text { orang } \\ \text { (Q.S Ali-Imron, 3:159) }\end{array}$
Selain itu juga evaluasi yang dilakukan BMT Amanah Ummah bertujuan untuk menganalisis internal organisasi dan eksternal organisasi dengan tujuan untuk mengetahui apakah ada kekuatan, kelemahan, peluang, dan ancaman yang berguna untuk perbaikan BMT Amanah Ummah.

Evaluasi dilakukan BMT Amanah Ummah secara rutin tiap bulan, tiap enam bulan, dan setiap tahun. Pada dasarnya evaluasi yang dilakukan BMT Amanah Ummah sesuai dengan teori Fred R. David yang melakukan evaluasi atas dasar kinerja organisasi baik dari kinerja karyawan, kinerja keuangan, kinerja operasional, kinerja pemasaran, dll.

\section{SIMPULAN}

Berdasarkan hasil penelitian yang dilakukan pada proses manajemen strategik syariah yang dilakukan oleh BMT Amanah Ummah yang meliputi perumusan strategi, implementasi strategi, dan evaluasi strategi maka dapat disimpulkan bahwa:

a. Proses perumusan strategi yang dilakukan BMT Amanah Ummah dilakukan dengan cara musyawarah antara pengurus dengan seluruh staff. Dalam perjalanannya BMT Amanah Ummah pernah melakukan perubahan visi, pada dasarnya BMT Amanah Ummah berusaha 
agar visi dapat diubah selama lima atau sepuluh tahun agar dapat mengikuti perkembangan usaha. Perumusan misi yang dilakukan BMT Amanah Ummah dilandasi oleh cara Rasulullah Muhammad SAW dalam mengajarkan agama Islam. Dalam hal ini Rasulullah mengedepankan cara-cara yang ditempuh (misi) yaitu melalui pendekatan-pendekatan kepada masyarakat Arab yang notabenenya adalah masyarakat jahiliyah menjadi masyarakat yang mempunyai peradaban yang baik. Hal itulah yang menjadi pertimbangan BMT Amanah Ummah dalam mengedepankan misi dengan cara-cara pendekatan kepada masyarakat. Pada dasarnya BMT Amanah Ummah merupakan lembaga keuangan syariah yang mempunyai prinsip tidak hanya mencari profit atau keuntungan, tetapi mendekatkan masyarakat kepada ekonomi Islam dengan cara berdakwah. Selain itu perumusan strategi menjadi dasar dalam melaksanakan kegiatan operasional sehari-hari. Akan tetapi kekurangan dari perumusan strategi ini terletak pada menentukan matriks yang masih sederhana yaitu matriks SWOT.

b. Pengelolaan karyawan yang dilakukan BMT Amanah Ummah dalam proses implementasi strategi yaitu dengan cara pemberian gaji yang sesuai dengan UMR, adanya insentif dan tunjangan, jenjang karir dan promosi jabatan. Dalam hal ini BMT Amanah Ummah berfokus pada pengembangan kapabilitas dan kemampuan kinerja karyawan, oleh karena itu BMT Amanah Ummah sering mengadakan seminar, workshop, coaching, dan juga outbound. BMT Amanah Ummah juga rutin mengadakan kajian-kajian Islam untuk para karyawan agar akhlak dan perilaku para karyawan senantiasa dapat berpedoman pada AlQur'an. Sedangkan dalam evaluasi strategi yang dilakukan BMT Amanah adalah dengan cara rapat dan musyawarah oleh para pengurus dan para staff berdasarkan hasil kinerja karyawan, kinerja keuangan, dan kinerja pemasaran. Hasil evaluasi yang telah dilakukan harus transparan agar para pengurus, staff, dan karyawan dapat mengetahui hasil kinerjanya masingmasing. Evaluasi strategi yang dilakukan BMT Amanah Ummah yaitu setiap akhir bulan, tiap enam bulan, dan tiap akhir tahun. Evaluasi strategi sendiri menentukan anggaran-anggaran kedepan, mengkoreksi kekurangan internal dan mencari peluang-peluang pasar, dan juga mengubah strategi dan visi apabila diperlukan.

\section{SARAN}

\section{a. Bagi BMT Amanah Ummah}

Pada dasarnya BMT Amanah Ummah sudah sangat bagus dalam menerapkan manajemen strategik syariah. Hal terbsebut dapat dilihat dari proses tahapan manajemen strategik syariah yang professional dan runtut. Oleh karena itu diharapkan BMT Amanah Ummah dapat senantiasa menerapkan prinsip syariah secara menyeluruh dalam 
melaksanakan proses manajemen strategik syariah. Diharapkan kedepannya BMT Amanah Ummah dapat melakukan investasi dibidang teknologi keuangan dan teknologi informasi manajemen yang berbasis syariah, agar prisnsip syariah dapat diterapkan secara seutuhnya.

\section{b. Bagi Masyarakat}

Perkembangan BMT yang cepat tentu membawa pengaruh yang baik kepada perekonomian syariah, dengan tumbuhnya lembaga keuangan syariah diharapkan masyarakat dapat memiliki alternatif lain dalam hal menyimpan dana dan mengajukan pembiayaan, khususnya bagi para pemilik dana lebih (mudharib) agar menyimpan dan menginvestasikannya di BMT, karena hal tersebut dapat menumbuhkan kesejahteraan masyarakat, selain itu agar masyarakat khususnya umat Islam dapat menerapkan prinsip syariah dan ikut serta dalam mengembangkan kegiatan ekonomi Islam. Tentunya butuh dukungan penuh dari masyarakat, pihak-pihak terkait seperti pemerintah, dan stakeholders.

\section{DAFTAR PUSTAKA}

Al-Qur'an dan Terjemahannya. 2005. Syamil AIQur'an. Bandung: PT. Syamil Cipta Media.

Arifin, Zainal. 2005. Teori Keuangan dan Pasar Modal. Yogyakarta: Ekonisia.
Arikunto, Suharsimi. 1998. Prosedur Penelitian: Suatu Pendekatan Praktek. Jakarta: Rineka Cipta.

Aziz, M. Amin. 2004. Tata Cara Pendirian BMT. Jakarta: PKES Publishing

Basrowi dan Suwandi. 2008, Memahami Penelitian Kualitatif. Jakarta: Rineka Cipta.

Beekun. 2011. Strategic Management for Is/amic Organization. Kuala Lumpur.

David, Fred. 2011. Manajemen Strategis: Konsep. Jakarta: Salemba Empat

Departemen Pendidikan dan Kebudayaan. 1991. Kamus Besar Bahasa Indonesia. Edisi Kedua. Jakarta: Balai Pustaka.

Djazuli dan Janwari. 2002 LembagaLembaga Perekonomian Umat (Sebuah Pengenalan). Jakarta: PT. Raja Grafindo Persada.

Yabqi, Faid. 2014. Manajemen Pembiayaan Macet Murabahah di BMT Mandiri Sejahtera Gresik. Skripsi Universitas Airlangga.

Hafidhhuddin, Didin. 2002. Manajemen Syariah dalam Praktik. Jakarta: Gema Insani

Hamel dan Pralahad. 1996. Competiting for The Future. Boston: Harvard Bussiness School Press

Higgins, James $\quad$ M. 1995. OrganizationalPolicy and Strategic Management. New York City: Henry Holt and Company.

Hitt, Michael A. 1997. Strategic Management Concepts. Boston: Cengage Learning. 
IImi, Makhalul. 2002. Teori dan Praktek Lembaga Mikro Kevangan Syariah. Yogyakarta: UII Press.

Jogiyanto, H.M. 2005. Sistem Informasi Strategik. Yogyakarta: Andi Publisher Karebet, Muhammad. 2002. Pengantar Manajemen Syariat. Jakarta: Khairul Bayaan.

2003. Manajemen

Strategis Perspektif Syariah. Jakarta: Khairul Bayaan

Kotler dan Andreasen. Strategic Management for Non Profit Organization. New Jersey: Prentice Hall. Kuncoro, Mudrajad. 2003. Metodologi Riset Untuk Bisnis dan Ekonomi. Jakarta: Ghalia Indonesia

Krisyanto, Rahmad. 2005. Metodologi Penelitian Sosial. Surabaya: Airlangga Marrus, Stephanie K. 1994. Building the Strategic Plan: Find, Analyze, and Present the Right Information. Florida: Krieger Publishing Company.

McCarthy, Jerome E. Basic Marketing: A Managerial Approach $9^{\text {th }}$ Edition. Toronto: Irwin Professional Publishing Mualim, Amir dan Zainal Abidin. 2005. Profesionalisme Praktisi BMT Di Kota Yogyakarta Dan Kabupaten Sleman. Yogyakarta: Magister Studi Islam Universitas Islam Indonesia (MSI-UII).

Muhammad. 2012. PengantarManajemen Berbasis Islam (http://www.scribd.com/doc14350663manajemen-islam) (diakses pada 28 November 2014)
Moleong, Lexy J. 2000. Metode Penelitian Kualitatif. Bandung: PT. Remaja Rosdakarya.

Oktina, Maya. 2012. Implementasi Manajemen Strategik Bagi Peningkatan Etos Kerja Karyawan di PT. Toha Putra Semarang. Skripsi Universitas Diponegoro Bandung.

P3El. 2008. Ekonomi Islam. Jakarta: Rajawali Press.

Palalloi, Ahmad. 2012. Manajemen Strategik, Perumusan, Implementasi, dan

Evaluasi(http://www.palalloi.web.id/m mt/20MANAJEMEN\%20STRATEGI-1.pdf) (diakses pada 29 November 2014)

Pearce, dkk. 1997. Manajemen Strategik: Formulasi, Implementasi, Pengendalian, Jakarta: Binarupa Aksara

Pearce dan Robinson. 2013. Manajemen Strategis: Formulasi, Implementasi, dan Pengendalian, Jakarta: Salemba Empat.

Porter, Michael E. 1979. Competitive Strategy: Techniques for Analyzing Industries and Competitors. Washington D.C: Free Press 2001. Strategi Bersaing (Competitive Strategy), Terjemahan. Tangerang: Kharisma Publishing Group. Qur'an in Word Ver 1.3 created by Mohammad Taufia Republika Online. 2009. BMT Kelola Aset Rp 3

Triliun (http://www.republika.co.id/berita /bisnis-syariah/bmt/10/10/20/141197- 
bmt-indonesia-kelola-aset-rp-3-triliun)

(diakses pada 18 Oktober 2014)

Rivai, Veithzal. 2013. Islamic Risk Management for Islamic Bank. Jakarta: Bumi Aksara.

Salusu, J. 1996. Pengambilan Keputusan Stratejik: Untuk Organisasi Publik dan Organisasi Non Profit. Jakarta: Grasindo Seibel, Hans Dieter. 2008: 86-103. Islamic Micro finance in Indonesia: The Challenge of Institutional Diversity, Regulation, and Supervision. "Journal of Social Issues in Southeast Asia.

Sharplin, Arthur D. 1985. Strategic Management. New York City: McGrawHill Education

Silalahi, Gabriel Amin. 2003. Metodologi Penelitian dan Studi Kasus. Jakarta: Kompas

Soemitra, Andri. 2009. Bank dan Lembaga Kevangan Syariah. Jakarta: Kencana.

Sugiyono. 2005. Memahami Penelitian Kualitatif. Bandung: Alfabeta.

Suryana. 2010 Manajemen Strategik Untuk Bisnis dan Organisasi Non Profit. Jakarta: Salemba Empat

Suwarsono, Muhammad. 2008. Manajemen Strategi dan Konsep Edisi 4. Jakarta: Stim ykp

Suyanto, Muhammad, 2008. Business Strategy and Ethics. Yogyakarta: Andi Press

Antonio, Muhammad Syafi'i. 2005. Bank Syariah: Dari Teori ke Praktik. Jakarta: Gema Insani

Ula, Fery Risdanil. 2012. Implementasi Manajemen Strategik Syariah di
Organisasi Pengelola Zakat (Studi Kasus di Yatim Mandiri dan BAZ Jatim). Skripsi Universitas Airlangga.

Umar, Husein. 2003. Strategic Management in Action: Konsep, Teori, dan Teknik Menganalisis Manajemen Strategis Strategic Business Unit Berdasarkan Konsep Michael R Porter, Fred $R$ David, dan Wheelen-Hunger. Jakarta: Gramedia Pustaka Utama.

Wardiwiyono, Sartini. 2012. International Journal of Islamic and Middle Eastern Finance and Management:Internal control system for Islamic micro financing: An exploratory study of Baitul Maal wat Tamwil in the City of Yogyakarta Indonesia. Braford: Emerald Group Publishing Limited.

Warjiyo, Perry. 2004. Kebijakan Moneter di Indonesia. Jakarta: Pusat Pendidikan dan Studi Kebanksentralan

Widyanto dan Ismail. Improving the Effectiveness of Islamic Micro-financing: Learns from BMT Experience. Humanomics, International Journal of Systems and Ethics (Vol. 26 No. 1).

Wheelen dan Hunger. 1990. Strategic Management $7^{\text {th }}$ Edition. New Jersey: Prentice Hall.

Yin. Robert K. 2002. Studi Kasus: Desain dan Metode, Terjemahan. Jakarta: PT. Grafindo Persada.

Yusanto dan Widjajakusuma. 2002. Menggagas Bisnis Islami. Jakarta: Gema Insani. 
JESTT Vol. 2 No. 12 Desember 2015

Zadjuli, Suroso Imam. 1999. Prinsip-Prinsip

Ekonomi Islam. Surabaya: Fakultas

Ekonomi Universitas Airlangga.

Zallum, Abdul Qadim. 1983. Al Amwal Fi

Daulah Al Khilafah $1^{\text {st }}$ edition Beiru:Darul

IIm Lil Malayin. 